\title{
THE USE OF ICE BREAKER TO IMPROVE STUDENTS' MOTIVATION IN LEARNING ENGLISH AT THE TENTH GRADE STUDENTS OF SMK YPKKP
}

\author{
Previa Rahmayanti ${ }^{1}$, Putri Ayuna Saraswati ${ }^{2}$, Gartika Pandu Bhuana ${ }^{3}$ \\ ${ }^{1}$ IKIP Siliwangi \\ ${ }^{2}$ IKIP Siliwangi \\ ${ }^{3}$ IKIP Siliwangi \\ 1'previarahma24@gmail.com, ${ }^{2}$ putriayuna10@gmail.com, ${ }^{3}$ gartikapandu@gmail.com
}

\begin{abstract}
There is a belief that ice breaking can be used in the classroom as it provides several advantages for the students. One of them is that it can improve students' learning motivation. This study aims to prove this belief. In other words, it attempts to investigate the effectiveness of ice breaking in improving students' learning motivation. Quantitative with one group pretest and posttest was used in this study. The population was the 10th grade students at SMK YPKKP. The sample was one class of office administration major. The data was collected through motivation test adapted from (Burhan, 2017). The result showed that null hypothesis of this study was rejected. It is proved by the data from t-test that shows the sigma 2 tailed is 0.00 . This value is less than 0.05 . Null hypothesis, therefore, was rejected. This means that ice breaking could definitely improve the students' motivation in learning English. The teacher therefore can implement it in the classroom. in the title.
\end{abstract}

Keywords: Students' motivation, Learning, English

\section{INTRODUCTION}

Pre-observation data showed that there are several problems dealing with students' motivation in learning English at SMK YPKKP, especially at the tenth grade of administration program. This can be seen from the students' enthusiasm in learning English. Most of them did not pay attention to the teacher's explanation during the lesson. They tended to talk with their friend. They even rarely finished the task given by the teacher. The reason was they could not do it.

According to Damayanti (2016) as cited in Cahyati, Parmawati, \& Atmawijaya (2018), teaching and learning English as a foreign language has different learning situations, such as limited time allocated to English lessons, large class size, students' low motivation, and form-focused exams. There is always a solution in every problem, so is with the above problem. The teacher here can use an attractive method or technique in teaching an English language. One of attractive that is rare to be used is ice breaker. Ice breaker is a technique to melt a clumsy atmosphere. It is often used in conversation. However, it also can be used in a classroom. Sinta (2018) says that in a classroom, ice breaker can switch the situation. It can raise a learning spirit in the class. As a result, the students is more motivated to learn (Dewi, 2015). 
Ice breaker can be conducted spontaneously and conceptually. It can be used in the beginning, middle or in the end of the lesson. In the beginning of the lesson, it is like a warm up. It can raise the students' spirit to learn. In the middle, it can regain the students' concentration and attention. Meanwhile, at the end, it can create addiction sense to the students to learn.

Several studies have been conducted in the area of ice breaker technique and students' learning motivation. Most of them were conducted in secondary school, and discovered the effectiveness of ice breaker in improving students' speaking skill. There have no the study that is investigating the use of ice breaker in vocational school yet. Therefore, this study aims to fill this gap by implementing ice breaker at SMK YPKKP. The null hypothesis of this study is ice breaking is not effective in improving students' motivation in learning English.

\section{Motivation}

Literally, McMillan dictionary (1979) defines motivation as providing a motive, moving to effort or an action. Bhuana (2017) states that motivation is a desire to gain a goal. This implies that motivation is a favorable attitude in achieving the determined goal. Motivation plays an important role in learning. As cited by Apsari (2014) who state that motivation plays a vital role in reading a foreign language. Thus, motivation determines the success of learning. Waugh (2004 in Bhuana, 2017) classifies motivation into two types: integrative and instrumental motivation. Integrative motivation de als with the intention to become a part of the target language community (Bhuana, 2017). The learner who have this type of motivation want to learn a language because they want to know more the culture of the language. Meanwhile, instrumental motivation deals with practical needs (Bhuana, 2017). The learners here learn a language as they want to get a better job, higher salary and bonus (Bhuana, 2017).

\section{Ice Breaker}

Ice breaker is every activity that is applied by the teachers in the classroom to make the students get interested in learning (Yeganehpour, 2017). Forbes \& Greene (in Yeganehpour, 2017) three types of ice-breaker. The first one is openers. The aim is to warm up the students by challenging and motivating them. This kind of ice breaker can be used to begin a session or a discussion, or to introduce a new topic. The second types was energizer. This ice breaker is used when the students feel stresses or do not enthusiasm in learning. The last one is feedback and disclosure. This is used to demonstrate a communication variable. It can be conducted at the end of the lesson to check the students' understanding of the learned material. Regarding the activities, ice breaker can be in many kind of forms. Zhang (2000) in Yeganehpour (2017) gives the example, such as reading stories, question and answer, using picture, games, etc.

Several expert (such as Yeganehpour, 2016; (Hutasoit \& Tambunan, 2019) believe that ice breaker provide several advantages to the learning process. It can help the teacher to create joyful and conducive learning. The students, here, will fell relax and comfortable in learning. They will also have a good mood of learning. Besides, it can increase students' motivation, comprehension and full involvement in the learning activity.

\section{METHOD}

This study was quantitative with one group pretest-and- posttest design. The population was $10^{\text {th }}$ grade students at a vocational school in Bandung. Not all the population was chosen as the sample. This study only took one class at administration program. This class consisted of 28 
students. This class was selected as during the internship program conducted by the researcher, the students here were very reluctant to speak or even learn English. In other words, they had low motivation to learn English. The investigated class was then given a treatment, ice breaking. The treatment was conducted 3 times, from $3^{\text {rd }}$ October 2018 to $24^{\text {th }}$ October 2018.

To collect the data needed, this study used motivation test that asked several question related to the students' motivation in learning English. The test was adapted from (Burhan, 2017). It was in the form of 4-point Likert Scale (see Appendix). The test was given two times, before and after the treatment. The aim was to know the change of students' motivation before and after the treatment applied. The result of the test was then classified into the following table:

Table 1. Category of Motivation by Depdikbud (Sudirman 2009 in Burhan, 2017)

\begin{tabular}{ccc} 
No. & Motivation Category & Interval Score \\
\hline 1. & Less & $1-16$ \\
\hline 2. & Low & $17-32$ \\
\hline 3. & Enough & $33-48$ \\
\hline 4. & Good & $49-65$ \\
\hline 5. & Very Good & $66-82$
\end{tabular}

The collected data was then analyzed by using SPSS version 25 . In analyzing the data, the mean and standard deviation of students' test was counted. Besides, the normality and the normality of the data was also tested. The t-test was then used to investigate the difference of students' motivation before and after giving the treatment.

\section{RESULTS AND DISCUSSION}

\section{Results}

\section{Students' Pretest and Posttest}

As previously mentioned, this study used motivation test. The test consisted of 20 questions which was given before and after the treatment. The result can be seen in the following table:

Table 2. The result of students' pre-test and post-test

\begin{tabular}{clcc} 
& \multicolumn{1}{c}{ Students } & Pretest & Posttest \\
\hline 1 & student1 & 32 & 59 \\
\hline 2 & student2 & 43 & 70 \\
\hline 3 & student3 & 44 & 71 \\
\hline 4 & student4 & 44 & 68 \\
\hline 5 & student5 & 49 & 63 \\
\hline 6 & student6 & 44 & 63 \\
\hline 7 & student7 & 46 & 70 \\
\hline 8 & student8 & 35 & 66 \\
\hline 9 & student9 & 35 & 70 \\
\hline 10 & student10 & 41 & 65 \\
\hline 11 & student11 & 24 & 60 \\
\hline 12 & student12 & 47 & 63 \\
\hline 13 & student13 & 40 & 66 \\
\hline 14 & student14 & 35 & 68
\end{tabular}




\begin{tabular}{llll}
15 & student15 & 42 & 66 \\
\hline 16 & student16 & 46 & 70 \\
\hline 17 & student17 & 49 & 64 \\
\hline 18 & student18 & 43 & 57 \\
\hline 19 & student19 & 54 & 65 \\
\hline 20 & student20 & 46 & 63 \\
\hline 21 & student21 & 36 & 63 \\
\hline 22 & student22 & 45 & 61 \\
\hline 23 & student23 & 39 & 66 \\
\hline 24 & student24 & 43 & 63 \\
\hline 25 & student25 & 45 & 71 \\
\hline 26 & student26 & 47 & 66 \\
\hline 27 & student27 & 37 & 67 \\
\hline 28 & student28 & 37 & 67
\end{tabular}

From the above table it can be seen that the lowest score in pretest was 24 , while the highest score was 54. On the other hand, in posttest, the lowest score was 57, while the highest score was 71 . This indicates that the students' learning motivation after giving the treatment improved rather than before giving the treatment. Regarding the classification of students' learning motivation, it can be seen in the following table:

Table 3. The Frequency Distribution and Percentage of Students' Pre-test and Posttest score.

\begin{tabular}{ccccccc} 
No & $\begin{array}{c}\text { Motivation } \\
\text { Category } \\
\text { Range Score }\end{array}$ & Range & \multicolumn{2}{c}{ Pre-test } & \multicolumn{2}{c}{ Post-test } \\
\cline { 3 - 6 } & & $\mathrm{F}$ & $\begin{array}{c}\mathrm{P} \\
(\%)\end{array}$ & $\mathrm{F}$ & $\begin{array}{c}\mathrm{P} \\
(\%)\end{array}$ \\
\hline 1 & Less & $1-16$ & 0 & 0 & 0 & 0 \\
\hline 2 & Low & $17-32$ & 2 & $7,14 \%$ & 0 & 0 \\
\hline 3 & Enough & $33-48$ & 24 & $85,72 \%$ & 0 & 0 \\
\hline 4 & Good & $49-65$ & 2 & $7,14 \%$ & 14 & $50 \%$ \\
\hline 5 & Very Good & $66-82$ & 0 & 0 & 14 & $50 \%$ \\
\hline & $\quad$ Total & & 28 & $100 \%$ & 28 & $100 \%$
\end{tabular}

The table above shows that from the 28 students who followed the pre-test; two students (7.14\%) were in low category, 24 students $(85.72 \%)$ were in enough category, and two (7.14\%) were in good category. Meanwhile, in post-test, fourteen students $(50.0 \%)$ were in good category and fourteen students $(50.0 \%)$ were in very good category. This means that the score and the percentages of the score in post-test are better than in the pre-test.

Meanwhile the mean score and the standard deviation of pretest and posttest is provided in the table below:

Table 4. Total Mean Score Standard Deviation of the Students in Pre-test and Posttest score.

\begin{tabular}{|c|c|c|c|c|}
\hline \multirow[b]{2}{*}{$\begin{array}{l}\text { Class } \\
\text { erimental }\end{array}$} & \multicolumn{2}{|c|}{ Pre-test } & \multicolumn{2}{|c|}{ Post-test } \\
\hline & Mean score & $\begin{array}{l}\text { Standard } \\
\text { deviation }\end{array}$ & Mean score & $\begin{array}{c}\text { Standard } \\
\text { deviation }\end{array}$ \\
\hline
\end{tabular}



41.71
6.211
65.39
3.675

The above table shows that the mean score of students' pretest was 41.71, while posttest was 65.39. Meantime, the standard deviation of pretest was 6.211, while posttest was 3.675. This score, again, indicates that the students' posttest was better than the students' pretest. In other words, ice breaking was able to improve students' motivation in learning English.

\section{Normality}

Normality test was used to test the distribution of data. This test is used to determine whether the distribution of the data from the sample is normal. If the normality is more than the level of significance $\alpha(0.05)$, the data is normally distributed (Tri, 2015). The result of normality test can be seen below:

Table 4. Test of Normality

\section{Tests of Normality}

\begin{tabular}{lr|r|r|r|r|r|} 
& \multicolumn{3}{c}{ Kolmogorov-Smirnov } & \multicolumn{3}{c}{ Shapiro-Wilk } \\
& Statistic & \multicolumn{1}{c|}{ df } & \multicolumn{1}{c|}{ Sig. } & Statistic & \multicolumn{1}{c}{ df } & \multicolumn{1}{c}{ Sig. } \\
\hline Pretest & .153 & 28 & .090 & .952 & 28 & .229 \\
\hline Posttest & .115 & 28 & $.200^{*}$ & .958 & 28 & .308 \\
\hline
\end{tabular}

Based on the result above, the value of Sig. pretest was 0.90 and posttest was 0.200 . It showed that the value was more than the level of significance. It, therefore, can be concluded that the data of this present study has normally distributed.

\section{Homogeneity}

(Riadi, 2014) says homogeneity test is used to test whether the distribution of data from two or more variants comes from a homogeneous population or not, that is by comparing two or more variances. The result of homogeneity test can be seen below:

Table 5. Test of Homogeneity

Test of Homogeneity of Variances

\begin{tabular}{|c|c|c|c|c|c|}
\hline & & Levene Statistic & df1 & df 2 & Sig. \\
\hline \multirow[t]{4}{*}{ Pretest } & Based on Mean & .066 & 1 & 26 & .799 \\
\hline & Based on Median & .066 & 1 & 26 & .800 \\
\hline & $\begin{array}{l}\text { Based on Median and with } \\
\text { adjusted Dr }\end{array}$ & .066 & 1 & 25.618 & .800 \\
\hline & Based on trimmed mean & .066 & 1 & 26 & .800 \\
\hline \multirow[t]{2}{*}{ Posttest } & Based on Mean & .001 & 1 & 26 & .972 \\
\hline & Based on Median & .000 & 1 & 26 & 1.000 \\
\hline
\end{tabular}


Volume 2, No. 5, September 2019 pp 594-600

\begin{tabular}{l|r|r|r|r}
\hline $\begin{array}{l}\text { Based on Median and with } \\
\text { adjusted Dr }\end{array}$ & .000 & 1 & 21.859 & 1.000 \\
\hline Based on trimmed mean & .004 & 1 & 26 & .951 \\
\hline
\end{tabular}

From the result of homogeneity test above, it could be seen that the significance of the data from pretest score was 0.800 and the posttest was 0.951 . It means the significance of the data is higher than the significance degree $(\alpha=0.05)$. The result of homogeneity tests shows that pretest and posttest score was homogeny so that it can be tested by using t-test.

\section{T-test}

The $\mathrm{T}$ test is also called the hypothesis test. The test was conducted to test whether the hypothesis proposed is accepted or not. As (Sudijono, 2009) says that t-test is one of the statistical tests used to test the truth or falsehood of the null hypothesis which states that two sample mean is no significance difference. The result of t-test can be seen below:

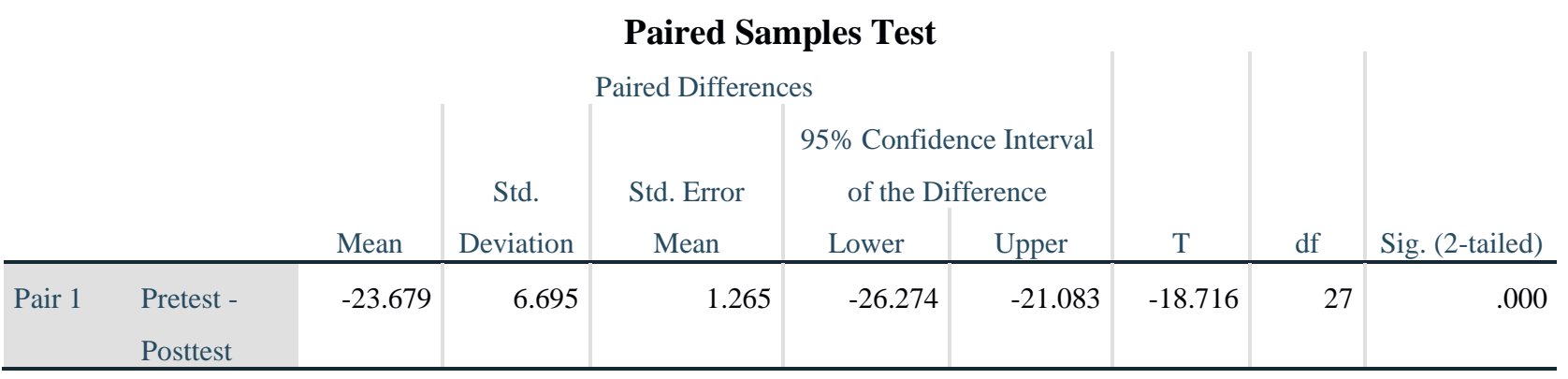

The table showed that Sig-2 tailed was 0.00. This was lower than 0.05. This means that Ho of this study was accepted. In the other words, there is the difference of students' learning motivation before and after giving the treatment. The use of ice breaking, here, is effective in improving students' learning motivation in English.

As previously discussed in the previous chapter, ice breaking offers various benefits in the process of learning. When the ice breaking is used in the beginning of the lesson, for example, it could catch the students' attention. The students were more enthusiast in learning (Hutasoit $\&$ Tambunan, 2019). When it was used as an energizer (in the middle of the lesson), it could relieve the students' stress from learning (Forbes \& Greene in Yeganehpour, 2017)). Ice breaking also could be used to regain the students' attention when they lost their focus. As a result, they have a good comprehension and understanding to the learned topic. It is showed by their participation in answering the teacher's questions. 


\section{CONCLUSION}

Based on the result of this study, ice breaking is effective in improving students' motivation in learning English. It is proved by the data from t-test that shows the sigma 2 tailed is 0.00 . This value is less than 0.05 . Null hypothesis, therefore, is rejected.

Based on the result of this study, it is suggested for the teacher who have students' with low motivation in learning English to use ice breaking in the learning and teaching process. This study shows that ice breaking can make students' to be more enthusiast in learning as it provides joyful activities. It also can regain the students' attention while they make some noise in the classroom.

\section{ACKNOWLEDGMENTS}

Alhamdulillah all gratitude to Allah S.W.T who gave His blessing to researchers, so researchers can finish this article with a good health condition. Researchers would like to say the biggest thank you for researchers' article supervisors who always gave researchers support when conducting this research. Also, researchers would like to say thank you to IKIP Siliwangi which gave us the opportunity to publish this article. Also for a blind reviewer who reviewed this article as well as to the editorial team so this article can be published perfectly.

\section{REFERENCES}

Apsari, Y. (2014). The use of authentic materials in teaching reading comprehension. ELTIN JOURNAL, Journal of English Language Teaching in Indonesia, 2(2).

Burhan, Zulhulaefah. (2017). The Effectiveness of the Application of Ice Breaker toward Improvment Students' Motivation in Learning English at the First Grade ff Mts Madani Alauddin Pao-Pao. Universitas Islam Negeri Alauddin Makassar.

Bhuana, G. P. (2017). Language Learning Motivation among Senior High School Students, 18.

Cahyati, S. S., Parmawati, A., \& Atmawidjaja, N. S. (2019). Optimizing English Teaching And Learning Process To Young Learners (A Case Study In Cimahi). Journal Of Educational Experts (Jee), 2(2), 107-114.

Dewi, S. K. (2015). Improving Students' Motivation in Learning ( Classroom Action Research at Eighth Grade of MTs Pembangunan ).

Hutasoit, R., \& Tambunan, D. B. (2019). The Effect of Ice Breaking Technique in Teaching Speaking at the Tenth Grade Students of SMK Dharma Bhakti Siborongborong in Academic Year 2018 / 2019, (5), 700-705.

Riadi, E. (2014). Metode Statistika Parametik \& Nonparametik: Untuk Penelitian ilmu-ilmu Sosial dan Pendidikan. Pustaka Mandiri.

Sinta. (2018). Improving Students Ability in Speaking by Using Ice Breaker Strategy at the Second Grade of MTS TPI Sawit Seberang in Academic Year 2017/2018.

Sudijono, A. (2009). Pengantar Statistik Pendidikan. Jakarta: PT. Raja Grafindo. Persada.

Tri, C. (2015). Statistik Uji Normalitas. Purwokerto: Yayasan Sanitarian Banyumas (YASAMAS).

Yeganehpour, P. (2016). Using Ice Breaker in Improving Every Factor which Considered in Testing Learners Speaking Ability. International Journal on New Trends in Education and Their Implications, (January), 58-68.

Yeganehpour, P. (2017). Ice-breaking as A Useful Teaching Policy for Both Genders, 8(22), 137-142. 